\title{
CLINICAL, GENETIC AND IMMUNOLOGICAL CHARACTERISTICS OF PAEDIATRIC AUTOIMMUNE POLYGLANDULAR SYNDROME TYPE 1 PATIENTS IN SLOVENIA KLINIČNE, GENETSKE IN IMUNOLOŠKE ZNAČILNOSTI OTROK IN MLADOSTNIKOV Z AVTOIMUNSKIM POLIGLANDULARNIM SINDROMOM TIPA 1 V SLOVENIJI
}

\author{
Nina BRATANIC ${ }^{1}$, Kai KISAND², Magdalena AVBELJ STEFANIJA ${ }^{1}$, Tadej BATTELINO ${ }^{1,3}$, \\ Katarina TREBUSAK PODKRAJSEK ${ }^{3,4, *}$ \\ 1 University Children's Hospital, Department of Pediatric Endocrinology, Diabetes and Metabolic Diseases, \\ Bohoriceva 20, 1000 Ljubljana, Slovenia \\ 2University of Tartu, Institute of Biomedicine and Translational Medicine, Ravila 19, 50411, Tartu, Estonia \\ ${ }^{3}$ University of Ljubljana, Faculty of Medicine, Vrazov trg 2, 1000 Ljubljana, Slovenia \\ ${ }^{4}$ University Medical Centre Ljubljana, University Children's Hospital, Unit for Special Laboratory Diagnostics, \\ Vrazov trg 1, 1000 Ljubljana, Slovenia
}

Introduction. Autoimmune polyglandular syndrome type 1 (APS-1) is an autosomal recessive disorder, caused by mutations in the AIRE gene. The major components of APS-1 are chronic mucocutaneous candidiasis (CMC),

Keywords: autoimmunity, APS-1, APECED, AIRE paediatric APS-1 patients were investigated.

Methods. Existing medical records of 15 APS-1 patients were rewieved, when necessary, additional clinical and laboratory investigations were issued. AIRE gene analysis was performed to identify causative mutations, and autoantibodies against type I interferons were measured by luminescence immunoprecipitation system.

Results. Patients had one to eight different manifestations of the disease. CMC was present in all, HP in 12/15 (80 $\%)$ and $A D$ in $8 / 15$ (53 \%) patients. Growth retardation, due to hyposomatotropism, growth hormone resistance, autoimmune thyroiditis, corticosteroid treatment, malabsorption or secretory failure of exocrine pancreas, was observed in altogether 7 (46 \%) patients. Six different AIRE gene mutations were detected and p.R257X mutation was present in $63.3 \%$ of pathological alleles. Antibodies against type I interferons were detected in all patients.

Conclusion. APS-1 is a rare disorder with a broad spectrum of clinical manifestations, which, if unrecognized or inadequately treated may be fatal. AIRE gene mutational analysis and autoantibodies against type I interferons are important in early identification of the disease. The aetiology of growth retardation was shown to be extremely diverse, frequently caused by less characteristic manifestations. APS-1 may affect patients' quality of life in numerous ways, and may cause great psychosocial burden leading to depression and suicidal thoughts even in paediatric patients.

\section{IZVLEČEK}

Ključne besede: avtoimunost, APS-1, APECED AIRE
Uvod. Avtoimunski poliglandularni sindrom tipa 1 (APS-1) je redka avtosomno recesivna bolezen, povezana z mutacijami gena AIRE. Tri najpomembnejše komponente APS-1 so kronična mukokutana kandidiaza (CMC), hipoparatiroidizem (HP) in Addisonova bolezen (AD). Raziskali smo klinične, genetske in imunološke značilnosti slovenskih pediatričnih bolnikov z APS-1.

Metode. Pregledali smo obstoječo medicinsko dokumentacijo 15 bolnikov z APS-1, v izbranih primerih smo opravili dodatne klinične in laboratorijske preiskave. Z genetsko analizo smo prepoznali vzročne mutacije gena AIRE, s sistemom luminiscenčne imunoprecipitacije (LIPS) pa smo določili avtoprotitelesa proti interferonom tipa 1.

Rezultati. Bolniki so imeli izraženo eno do osem različnih komponent bolezni. CMC je bila prisotna pri vseh bolnikih, HP pri 12 od 15 (80\%) in AD pri 8 od 15 (53\%). Zastoj rasti je bil prisoten pri 7 (46\%) bolnikih zaradi hiposomatotropizma, rezistence proti rastnemu hormonu, avtoimunskega tiroiditisa, zdravljenja s kortikosteroidi, malabsorbcije ali sekretorne okvare eksokrinega pankreasa. Prepoznanih je bilo 6 različnih mutacij gena AIRE, najpogostejša mutacija p.R257X je bila opredeljena pri 63,3\% mutiranih alelov. Avtoprotitelesa proti interferonom tipa 1 so bila prisotna pri vseh bolnikih.

Zaključki. APS-1 je redka bolezen s širokim naborom kliničnih značilnosti in je lahko smrtna, če ni prepoznana ali je neprimerno zdravljena. Za zgodnje odkrivanje sta ključnega pomena genetska analiza in določanje protiteles proti interferonom tipa 1. Pri bolnikih z APS-1 je zastoj rasti pogosta komponenta bolezni z različnimi vzroki, pogosto povezanimi z manj značilnimi manifestacijami. APS-1 na različne načine vpliva na kvaliteto življenja bolnikov in je veliko psihološko breme, ki lahko vodi v depresijo in samomorilne misli celo pri mladih bolnikih.

*Corresponding author: Tel: +386152292 98; E-mail: katarina.trebusak@kclj.si 


\section{INTRODUCTION}

Autoimmune polyglandular syndrome type 1 (APS-1) also known as autoimmune polyendocrinopathy-candidiasisectodermal dystrophy (APECED; OMIM 240300) is rare but devastating primary immunodeficiency disease. The range of clinical features is broad and very variable. The classic triad includes chronic mucocutaneous candidiasis (CMC), hypoparathyroidism (HP) and Addison's disease (AD). Patients may develop several other autiommune endocrine disorders (gonadal failure, type 1 diabetes, autoimmune thyroid disease) and nonendocrine disorders (ectodermal dystrophy, alopecia, vitiligo, chronic hepatitis...) (1). The disease usually begins in infancy with $C M C$, additional symptoms gradually appear later in life. Clinical diagnosis requires the presence of two of three major criteria (CMC, HP, AD). If a sibling has the syndrome, only one of the above manifestations is required. The prevalence is higher in genetically isolated populations; in Slovenia it was estimated to be 1:43,000 (2). APS-1 is caused by autosomal recessively inherited mutations in autoimmune regulator (AIRE) gene (3). AIRE gene is encoding transcriptional regulator principally expressed in medullary thymic epithelial cells (mTEC). AIRE plays an important role in maintaining self-tolerance and is involved in negative selection of autoreactive T-cells (4). The absence of AIRE results in impaired clonal deletion of self reactive thymocytes, which escape into the periphery and attack variety of organs resulting in different autoimmune diseases and presence of different organ specific autoantibodies (5). Additionally some nonorgan specific auto-antibodies are characteristic to APS-1. Antibodies against type I interferons, especially a and $\omega$ subtypes are reported to be highly specific for APS-1 (6). More recently, CMC in APS-1 patients have been associated with autoantibodies against Th17-related cytokines, primarily against IL-22 and IL-17F (7) showing that also CMC in APS-1 has an autoimmune basis.

\section{METHODS}

Fifteen APS-1 patients from thirteen unrelated Slovenian families were identified and included into the study. Mutational and partial clinical characteristics of patients 1 to 12 were previously reported $(2,8)$. Those patients were reinvestigated for the purposes of this study. The study protocol followed the Declaration of Helsinki and was approved by the national Ethical Committee (nr. 22/09/09, 28/2/13). Written informed consent was obtained by all participants or parents of minors prior to the study.
The patients' data were collected from existing medical records. The diagnosis of $H P, A D$, primary hypothyroidism, primary gonadal failure, pituitary failure were based on typical biochemical and endocrinological findings as described by others (9). We diagnosed oral candidiasis by visible mucosal changes in combination with positive Candida albicans culture and nail candidiasis by typical clinical findings or with the help of experienced dermatologist. Malabsorption was diagnosed from a history of recurrent episodes of diarrhea, growth retardation and/or measurement of fecal fat and pancreatic enzymes in stool. The duodenal and short bowel biopsy with chromogranin staining for detection of enterochromaffin cells was performed. Chronic elevation of liver enzymes without evidence of viral or drug-induced hepatitis was considered as suspected of autoimmune hepatitis. Consequently, liver biopsy and detection of autoantibodies against cytochrome P4501A2 (CYP1A2) were issued. Enamel hypoplasia was defined as defects in enamel not due to caries and the patients were evaluated by clinical examination and an orthopantomogram by an experienced dentist.

Genomic DNA was isolated from venous blood samples and AIRE gene exons were individually PCR amplified (2). Sequencing was performed using BigDye Terminator v.3.1 Cycle Sequencing Kit and 3500 Genetic Analyzer capillary electrophoresis system (Life Technologies, Foster City, USA). Identified variants were confirmed by the sequencing of at least two independent PCR products. Anti-IFN- $\alpha 2$, anti-IFN- $\alpha 8$, anti-IL-22, anti-IL-17A and antiIL-17F autoantibodies were measured in 12 out of 15 patients by luminescence immunoprecipitation system (LIPS) as previously described (10).

\section{RESULTS}

\subsection{Clinical Characteristics}

In surveys performed in 2005 and again in 2012 we were able to identify fifteen patients from thirteen families. Their clinical manifestations and the age of onset are shown in Table 1. All recruited patients but one had either two of the three major clinical manifestations or one in combination with blood relative with established APS-1. Mutational analysis confirmed the diagnosis in the patient with CMC as the only clinical manifestation. 
Table 1. Clinical and mutational characteristics in APS-1 patients (patients with growth retardation are marked with \#; mutations in bold were novel when detected, HP-hypoparathyroidism; AD-Addison's disease; CMC-mucocutaneous candidiasis; Alalopecia; ED-ectodermal dystrophy; KK-keratoconjunctivitis; Vi-vitiligo; T1D-type 1 diabetes, AH-autoimmune hepatitis; Hthypothyroidism; Ma-malabsorption; Hg-hypogonadism).

\begin{tabular}{|c|c|c|c|c|c|c|c|c|c|c|c|c|c|c|c|}
\hline \multirow{2}{*}{$\begin{array}{l}\text { Patient/ } \\
\text { Family }\end{array}$} & \multirow{2}{*}{ Gender } & \multirow{2}{*}{$\begin{array}{l}\text { Year of } \\
\text { birth }\end{array}$} & \multicolumn{12}{|c|}{ Clinical characteristics } & \multirow{2}{*}{ AIRE mutation } \\
\hline & & & $\mathrm{HP}$ & $A$ & CMC & Al & ED & KK & $\mathrm{Vi}$ & T1D & $\mathrm{AH}$ & $\mathrm{Ht}$ & Ma & $\mathrm{Hg}$ & \\
\hline \multirow[t]{2}{*}{$1 / \mathrm{A}$} & M & 1979 & 14 & 10 & 12 & & & & & & & & & & p. $\left[R 257^{*}\right] ;\left[R 257^{*}\right]$ \\
\hline & & & & & & & & & & & & & & & c. $[769 \mathrm{C}>\mathrm{T}] ;[769 \mathrm{C}>\mathrm{T}]$ \\
\hline \multirow[t]{2}{*}{$2 / \mathrm{A}$} & M & 1980 & 6,3 & & 17,5 & 7,0 & & & & & & & & & p. $\left[R 257^{*}\right] ;\left[R 257^{*}\right]$ \\
\hline & & & & & & & & & & & & & & & c. $[769 \mathrm{C}>\mathrm{T}] ;[769 \mathrm{C}>\mathrm{T}]$ \\
\hline \multirow[t]{2}{*}{ 3/B\# } & $\mathrm{F}$ & 1990 & 7,8 & 7,9 & 7,9 & & & & & & & & 13,5 & 20,9 & p. $\left[R 257^{*}\right] ;\left[R 257^{*}\right]$ \\
\hline & & & & & & & & & & & & & & & c. $[769 \mathrm{C}>\mathrm{T}] ;[769 \mathrm{C}>\mathrm{T}]$ \\
\hline \multirow[t]{2}{*}{$4 / C \#$} & M & 1990 & 6,5 & 6,4 & 6,5 & & 6,5 & 10,3 & & & & 11,1 & & 14,8 & p. $\left[R 257^{*}\right] ;\left[R 257^{*}\right]$ \\
\hline & & & & & & & & & & & & & & & c. $[769 \mathrm{C}>\mathrm{T}] ;[769 \mathrm{C}>\mathrm{T}]$ \\
\hline \multirow[t]{2}{*}{$5 / D$} & M & 1986 & 11,1 & 10,9 & 11,1 & & & 13,1 & & & & 25 & & & p. $\left[R 257^{*}\right] ;\left[R 257^{*}\right]$ \\
\hline & & & & & & & & & & & & & & & c. $[769 \mathrm{C}>\mathrm{T}] ;[769 \mathrm{C}>\mathrm{T}]$ \\
\hline \multirow[t]{2}{*}{ 6/E\# } & M & 1997 & 3,7 & 14,9 & 3,7 & 3,7 & 3,7 & & & & & 9,7 & 6,3 & & p. [R257*];[T16M] \\
\hline & & & & & & & & & & & & & & & c. $[769 \mathrm{C}>\mathrm{T}] ;[47 \mathrm{C}>\mathrm{T}]$ \\
\hline \multirow[t]{2}{*}{ 7/E\# } & $\mathrm{F}$ & 1992 & 5,5 & & 11,4 & & 5,5 & & & & & & 15,9 & & p. $\left[R 257^{*}\right] ;[T 16 M]$ \\
\hline & & & & & & & & & & & & & & & c. $[769 \mathrm{C}>\mathrm{T}] ;[47 \mathrm{C}>\mathrm{T}]$ \\
\hline \multirow[t]{2}{*}{$8 / F$} & M & 1977 & & 7,8 & 23,3 & & 7,8 & & & & & 26,3 & & 21,3 & p. $\left[\mathrm{R} 257^{*}\right] ;[\mathrm{R} 15 \mathrm{fs}]$ \\
\hline & & & & & & & & & & & & & & & c. $[769 \mathrm{C}>\mathrm{T}] ;[21-43$ dup23] \\
\hline \multirow[t]{2}{*}{ 9/G } & M & 1976 & 9,4 & & 24,5 & 9 & & & 11,6 & 21 & & 24,5 & & & p. $\left[R 257^{*}\right] ;[\mathrm{G} 180 \mathrm{fs}]$ \\
\hline & & & & & & & & & & & & & & & c. $[769 \mathrm{C}>\mathrm{T}] ;[540 \mathrm{delG}]$ \\
\hline \multirow[t]{2}{*}{ 10/H\# } & M & 1992 & & 8,5 & 3,6 & 3,6 & & & & & 3,6 & & & 17,8 & p. $\left[R 257^{*}\right] ;\left[R 257^{*}\right]$ \\
\hline & & & & & & & & & & & & & & & c. $[769 \mathrm{C}>\mathrm{T}] ;[769 \mathrm{C}>\mathrm{T}]$ \\
\hline \multirow[t]{2}{*}{$11 / \mathrm{I} \#$} & $\mathrm{~F}$ & 1998 & 3,8 & 4,0 & 4,6 & & & 12,5 & & & & & & 11,7 & p. [R257*];[?] \\
\hline & & & & & & & & & & & & & & & c. $[769 \mathrm{C}>\mathrm{T}] ;\left[653-7 \_-5 \mathrm{delCTC}\right.$ \\
\hline \multirow[t]{3}{*}{$12 / J \#$} & M & 1990 & 12,9 & & 0,3 & & 5,5 & & & & & 5,5 & 14,5 & 20,7 & p.[Q358fs];[Q358fs] \\
\hline & & & & & & & & & & & & & & & c. [1064-1068dupCCCGG]; \\
\hline & & & & & & & & & & & & & & & [1064-1068dupCCCGG] \\
\hline \multirow[t]{2}{*}{$13 / \mathrm{K}$} & M & 1998 & & & 1,8 & & & & & & & & & & p. [R15fs];[R15fs] \\
\hline & & & & & & & & & & & & & & & c.[21-43dup23];[21-43dup23] \\
\hline \multirow[t]{2}{*}{$14 / L$} & M & 2004 & 7,9 & & 5,8 & & & & & & & & & & p. [R15fs];[R15fs] \\
\hline & & & & & & & & & & & & & & & c. [21-43dup23];[21-43dup23] \\
\hline \multirow[t]{2}{*}{$15 / M$} & $\mathrm{~F}$ & 2009 & 3,3 & & 2,5 & & & & & & & & & & p. $\left[R 257^{*}\right] ;\left[R 257^{*}\right]$ \\
\hline & & & & & & & & & & & & & & & c. $[769 \mathrm{C}>\mathrm{T}] ;[769 \mathrm{C}>\mathrm{T}]$ \\
\hline
\end{tabular}


Among 11 boys and 4 girls, the onset of the disease ranged from 1,8 years to 10,9 years (mean 6,1 yr). HP was the first clinical manifestation in seven patients, $A D$ in five, autoimmune hepatitis, autoimmune thyroiditis and CMC each in one. In three patients with HP or autoimmune thyroiditis as first manifestation, review of the available clinical data revealed that MC was present much earlier.

The patients had one to eight clinical manifestations. CMC was present in all patients, HP in $12(80 \%), A D$ in 8 (53\%), autoimmune thyroiditis and hypogonadism each in $6(40 \%)$. Other clinical manifestations appeared less often (Figure 1). AD was diagnosed in all patients in the first decade of life. Mineralocorticoid deficiency preceded hypocorticism in $3 / 8$ patients $(5 / D, 6 / E$, $10 / H)$. Hypogonadism was diagnosed in 2 girls and 4 boys during or after pubertal development. One male patient $(4 / C)$ had secondary hypogonadism in the course of autoimmune hypophysitis, all other patients had primary hypogonadism. Keratoconjuctivitis was diagnosed in three patients. In one of $(4 / C)$ them the changes improved only after long term systemic cyclosporine treatment.

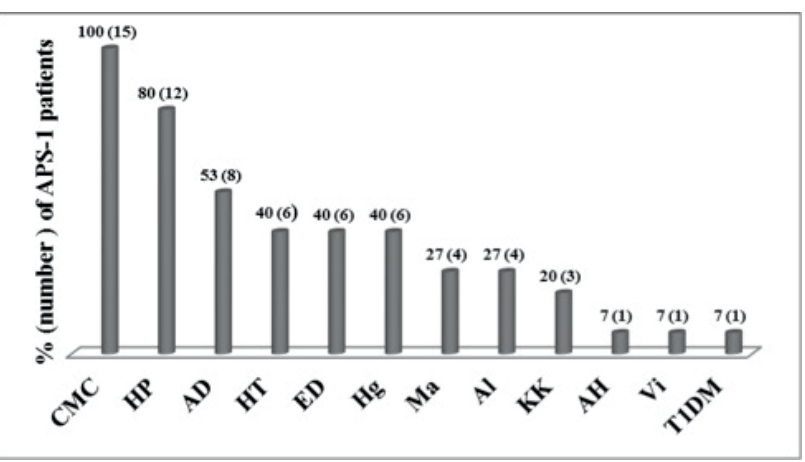

Figure 1. Number of patients affected by each manifestation of APS-1 (abbreviations as in Table 1).

Seven patients (46\%) had growth retardation from different causes shown in Table 2. Growth hormone deficiency was confirmed only in patient 4/C with secondary hypogonadism and several other clinical manifestations. In the female patient $11 / /$ exaggerated response during growth hormone stimulation test and normal growth factors were observed.
Table 2. Etiology of growth retardation in APS 1 patients.

\author{
Growth hormone deficiency \\ Growth hormone resistance \\ Chronic corticosteroid therapy \\ Hypothyroidism (autoimmune thyroiditis) \\ Malabsorption:
- Massive duodenal colonisation with Giardia lamblia
- Massive gastrointestinal colonisation with Candida albicans
- Exocrine pancreatic insufficiency
- Enteroendocrine cell loss

Autoimmune thyroiditis with myxoedema and severe growth retardation was the first clinical manifestation of APS-1 in patient $12 / \mathrm{J}$ at the age of 5,5 years. After starting treatment with L-thyroxine, his growth velocity increased and he reached normal growth curves. Growth failure reappeared at the age of 14 years when steatorrhea and pancreatic insufficiency was diagnosed. Chronic corticosteroid treatment of autoimmune hepatitis caused growth delay in patient $10 / \mathrm{H}$.

Depression was observed in three (4/C, 7/E, 11/I) patients who needed psychiatric support. During the study period, two young adult patients $(8 / F, 9 / G)$ died, both with severe psychological dysfunction. One died due to addisonian crisis, after having neglected therapy for a long time. The other patient most probably died because of insulin overdose.

\subsection{Mutational and Immunological Characteristics}

Six different AIRE gene mutations were detected among 15 APS-1 patients (Table 1), three of which were novel at the time (2). The most prevalent mutation in Slovenian APS-1 population was p.R257* (c.769C>T) present in $63.3 \%$ of pathological alleles, followed by p.R15fs (c.2143dup23) mutation in $16.7 \%$. Anti-IFN-a2, anti-IFN-a8 and anti-IL-22 autoantibodies in high titres were detected in all analysed patients (Table 3). Anti-IL-17A were detected in $41,7 \%$ and anti-IL-17F in $91,7 \%$ of APS-1 patients.

Table 3. Immunological characteristics of the APS-1 patients (the values represent times over the mean of healthy control values; negative values are in italic).

\begin{tabular}{lcccccc}
\hline & Clinical characteristics & anti-IFN-a2 & anti-IFN-a8 & anti-IL-22 & anti-IL-17A & anti-IL-17F \\
\hline 1/A & 3 & 133,2 & 69,2 & 382,4 & 0,7 & 13,7 \\
3/B & 5 & pos & pos & pos & pos & pos \\
4/C & 7 & 139,4 & 112,8 & 170,5 & 1,6 & 14,0 \\
5/D & 5 & 175,5 & 145,6 & 769,7 & 144,9 & 62,7 \\
6/E & 7 & 278,3 & 68,0 & 512,1 & 0,7 & 25,1 \\
\hline
\end{tabular}




\begin{tabular}{|c|c|c|c|c|c|c|}
\hline & Clinical characteristics & anti-IFN-a2 & anti-IFN-a8 & anti-IL-22 & anti-IL-17A & anti-IL-17F \\
\hline $7 / E$ & 4 & 149,0 & 126,1 & 210,5 & 0,7 & 0,8 \\
\hline $10 / H$ & 5 & 92,3 & 149,0 & 362,5 & 15,1 & 110,9 \\
\hline $11 / /$ & 5 & 101,1 & 132,0 & 605,8 & 2,2 & 201,7 \\
\hline $12 / J$ & 6 & 242,4 & 190,8 & 996,6 & 1,5 & 86,8 \\
\hline $13 / K$ & 1 & 280,9 & 66,3 & 353,8 & 114,6 & 7,7 \\
\hline $14 / L$ & 2 & 103,6 & 81,1 & 533,4 & 76,1 & 131,8 \\
\hline \multirow[t]{2}{*}{$15 / M$} & 3 & 73,6 & 127,2 & 411,0 & 3,8 & 159,9 \\
\hline & & $100 \%$ & $100 \%$ & $100 \%$ & $41,7 \%$ & $91,7 \%$ \\
\hline
\end{tabular}

\section{DISCUSSION}

While the majority of reports are focusing on adult APS-1 patients, so far there is only one report describing clinical and genetic characteristics of paediatric North Irish APS-1 patients (11). Here, we report extensive clinical, genetic and immunological overview of Slovenian paediatric APS-1 cohort.

Whereas all but one patient in our study group met standard diagnostic APS-1 criteria, there were striking clinical variations, even between siblings with identical AIRE mutations. Clinical manifestations showed similar prevalence and follow-up as in those reported in other studies (11-13). Especially as in Finnish patients, with whom the majority of Slovenian patients share the common p. R257* (c.769C>T) mutation (1). CMC was detected in all Slovenian and Finnish patients, while it was present in less than $20 \%$ of Iranian Jews patients, probably due to AIRE mutation present only in this community (14). On the contrary, type I diabetes was observed in only one Slovenian patient, but it is more frequent among Finnish patients (1).

The APS-1 patients were usually first admitted to our clinic because of clinical symptoms of hypoparathyroidism, Addison's disease, or symptoms of other endocrine or organ dysfunction, while it is possible that Candida albicans infection was present much earlier. At clinical examination, Candida infection was detected in 6 out of $15(40 \%)$ patients by the age of 5 , and in all of them by the age of 25 years old. This is comparable to the Finnish data, where $50 \%$ had candidiasis by the age of 5 and $97 \%$ by the age of 30 (15).

Only individual cases of growth failure in APS-1 have been published to date $(11,16,17)$. Nevertheless, growth failure as clinical presentation of various endocrine and nonendocrine dysfunctions, was observed in $46 \%$ of Slovenian patients. The patient $4 / \mathrm{C}$ with growth hormone deficiency had hypersensitivity to growth hormone, which has not been reported in APS-1 so far. During growth hormone treatment, systemic allergic reaction occurred and the treatment was discontinued. In the patient $11 / 1$ with growth hormone resistance, the treatment with high doses of growth hormone did not improve her growth velocity, despite a significant increase in the growth factors level. We speculated that antibodies against growth factors or growth factor receptors may be responsible, but further investigations are needed.

APS-1 should be considered in the differential diagnosis of gastrointestinal symptoms, such as malabsorption, constipation, watery diarrhea or steatorrhea, as they are reported in almost $24 \%$ of the APS-1 patients (17). Several studies demonstrated that gastrointestinal dysfunction (GD) in APS-1 patients is associated with severe or complete loss of enteroendocrine cells (18-20). Patients develop autoantibodies against tryptophan hydroxylase, the rate-limiting enzyme in the synthesis of serotonin, having a critical role in enteric function (19). The identification of mucosal antibodies and repeated clinical remission achieved with immunosuppressive treatment in a patient with recurrent episodes of diarrhea with steatorrhea clearly support the idea that GD is due to AIRE deficiency (21). We observed GD in four patients (3/B, $6 / \mathrm{E}, 7 / \mathrm{E}, 12 / \mathrm{J}$ ). All had intestinal candidiasis treated with systemic antifungal therapy, one of them additional massive duodenal colonisation with Giardia lamblia (7/E). Three patients $(6 / \mathrm{E}, 7 / \mathrm{E}, 12 / \mathrm{J})$ had recurring diarrhea and steatorrhea with exocrine pancreatic insufficiency, in two absence of enteroendocrine cells in intestinal biopsy was found.

Chronic endocrine disorders are known to impair patients' quality of life. APS-1 patients not only cumulate multiple endocrine disorders, requiring daily oral and lifelong hormonal replacement therapy, but the disease affects the quality of life in numerous ways: by life-threatening situations, disfiguring ectodermal manifestations, vision impairment, infertility and fear of developing additional components during life. Impairment of general health, emotional well-being and vitality were the most diminishing aspects of quality of life, with depressive 
symptoms affecting $29 \%$ of the adult APS-1 Finnish patients (22). Among Slovenian paediatric APS-1 patients, three developed depression and two young adults died. This is indicating the extent of the disease burden even in younger patients.

Over 95 different AIRE mutations have been identified, but two of them are found in the great majority of the patients. The p.Cys322fs (c.967_979del13) mutation is characteristic of North American, British and Norwegian patients (23), p.R257* (c.769C $>T$ ) is present in more than $85 \%$ of the Finnish patients and common among Central and Eastern European patients (12,24). Mutational spectrum of Slovenian APS-1 patients was consistent with other populations in the region, since p.R257* mutation was present in $63,3 \%$ of pathological AIRE alleles. The second most prevalent mutation was p.R15fs (c.2143dup23bp). This mutation was reported only in one Austrian and one Hungarian patient (24), and it seems to be restricted to the region. Other mutations are much rarer and present in isolated families.

A great variability in the prevalence of autoimmune hepatitis in different populations is reported, namely: $5 \%$ in Norwegian (25), 12 \% in Finish (9) and 27 \% in Sardinian patients (26). These populations differ highly in their AIRE gene mutational spectrum (23-25), and it seems that the prevalence of autoimmune hepatitis might be related to it. A great majority of Slovenian and Finnish APS-1 patients carry the same AIRE mutation, and the prevalence of autoimmune hepatitis in both cohorts is comparably low. The hallmark of APS-1 is a variety of different autoantibodies that develop in association with the disease, where numerous organ specific, but also non-organ specific, autoantibodes may be present. Among the latter, antibodies against $\alpha$ and $\omega$ subtypes of type I interferons are present in all patients with APS-1, and, additionally, only in patients with thymoma with associated myasthenia gravis, but not in other autoimmune disorders (27). The autoantibodies are reported to be present before the onset of the disease (6). In our group of patients, antiIFN- $\alpha 2$ and anti-IFN- $\alpha 8$ autoantibodies were present in all analysed patients, even in the patient $13 / \mathrm{K}$, whose only symptom was CMC, and who had an uncommon AIRE mutation. This was confirming their diagnostic value in children with incomplete APS-1 clinical presentation.

Chronic mucocutaneous candidiasis is a persistent or recurrent infection of nail beds, skin or mucosa. It is the most prevalent disease manifestation associated with APS-1, present in all Slovenian patients. CMC in APS-1 have been associated with autoantibodies against Th17related cytokines, revealing the link between CMC and AIRE deficiency. Neutralizing autoantibodies against IL-22 are present in $91 \%$, against IL-17F in $75 \%$ and/or against IL-17A in $41 \%$ of more than 150 analysed patients
(7). They are highly specific for CMC in APS-1, and are present only in thymoma patients, but not in numerous other autoimmune diseases. Interestingly, all investigated Slovenian patients had anti-IL-22 autoantibodies present. Anti- IL-17F autoantibodies were present in $91 \%$ of the patients, but anti-IL-17A were, as expected, less prevalent.

\section{CONCLUSION}

The phenotypical expression of the APS- 1 shows a wide variability even among siblings with the same genotype. In view of this heterogeneity, an early diagnosis of APS-1 can be challenging and often leading to a considerable diagnostic delay. Therefore, clinicians should be aware that the presence of even a minor component of APS-1 in children should prompt a careful investigation for other signs and symptoms of the disease, including genetic and immunological testing, thus allowing an early diagnosis and prevention of severe and life-threatening events. Growth failure in presented population was common, while its aetiology may be diverse and frequently caused by less characteristic manifestations of the syndrome. Psychological burden of the disease was evident and requiring professional psychosocial support in the selected cases.

\section{CONFLICTS OF INTEREST}

The authors declare that no conflicts of interest exist.

\section{FUNDING}

This work was partly supported by the Slovenian Research Agency grants J3-6800, J3-6798 and P3-0343.

\section{ETHICAL APPROVAL}

The study was approved by the Slovene National Ethical Committee (Nr. 22/09/09, 28/2/13).

\section{REFERENCES}

1. Perheentupa J. Autoimmune polyendocrinopathy-candidiasisectodermal dystrophy. J Clin Endocrinol Metab 2006; 91: 2843-50.

2. Podkrajsek KT, Bratanic N, Krzisnik C, Battelino T. Autoimmune regulator-1 messenger ribonucleic acid analysis in a novel intronic mutation and two additional novel AIRE gene mutations in a cohort of autoimmune polyendocrinopathy-candidiasis-ectodermal dystrophy patients. J Clin Endocrinol Metab 2005; 90: 4930-5.

3. Nagamine K, Peterson P, Scott HS, Kudoh J, Minoshima S, Heino M. et al. Positional cloning of the APECED gene. Nat Genet 1997; 17: 393-8. 
4. Liston A, Lasage S, Wilson J, Peltonen L, Goodnow CC. Aire regulates negative selection of organ-specific T-cells. Nat Immunol 2003; 4: 350-4.

5. Peterson P, Peltonen L. Autoimmune polyglandular syndrome type 1 (APS1) and AIRE gene: new views on molecular basis od autoimmunity. J Autoimmun 2005; 25: 49-55.

6. Meager A, Visvalingam K, Peterson P, Möll K, Murumägi A, Krohn K. et al. Anti-interferon autoantibodies in autoimmune polyendocrinopathy syndrome type 1. PLoS Med 2006; 3: e289.

7. Kisand K, Bøe Wolff AS, Podkrajsek KT, Tserel L, Link M, Kisand KV. et al. Chronic mucocutaneous candidiasis in APECED or thymoma patients correlates with autoimmunity to Th17-associated cytokines. J Exp Med 2010; 207: 299-308.

8. Podkrajsek KT, Milenković T, Odink RJ, Claasen-van der Grinten HL, Bratanic N, Hovnik T. et al. Detection of a complete autoimmune regulator gene deletion and two additional novel mutations in a cohort of patients with atypical phenotypic variants of autoimmune polyglandular syndrome type 1. Eur J Endocrinol 2008; 159: 633-9.

9. Ahonen P, Myllärniemi S, Sipilä I, Perheentupa J. Clinical variation of autoimmune -polyendocrinopathy-candidiasis-ectodermal dystrophy (APECED) in a series of 68 patients. N Engl J Med 1990; 322: 1829-36.

10. Kärner J, Meager A, Laan M, Maslovskaja J, Pihlap M, Remm A. et al. Anti-cytokine autoantibodies suggest pathogenetic links with autoimmune regulator deficiency in humans and mice.Clin Exp Immunol 2013; 171: 263-72.

11. Millar S, Carson D. Clinical phenotypes of autoimmune polyendocrinopathy-candidiasis-ectodermal dystrophy seen in the Northern Ireland paediatric population over the last 30 years. Ulster Med J 2012; 81: 118-22.

12. Betterle C, Greggio NA, Volpato M. Autoimmune polyglandular syndrome type 1. J Clin Endocrinol Metab 1998; 83: 1049-55.

13. Wolf ASB, Erichsen MM, Meager A, Magitta NF, Myhre AG, Bollerslev $J$. et al. Autoimmune polyendocrine syndrome type 1 in Norway: phenotypic variation, autoantibodies, and novel mutations in autoimmune regulator gene. J Clin Endocrinol Metab 2007; 92: 595603.

14. Zlotogora J, Shapiro MS. Polyglandular autoimmune syndrome type 1 among Iranian Jews. J Med Genet 1992; 29: 824-6.

15. Husebye ES, Perheentupa J, Rautemaa R, Kampe O. Clinical manifestations and management of patients with autoimmune polyendocrine syndrome type I. J Intern Med 2009; 265: 514-29.

16. Ward L, Paquette J, Seidman E, Huot C, Alvarez F, Crock P. et al. Severe autoimmune polyendocrinopathy-candidiasis-ectodermal dystrophy in an adolescent girl with a novel AIRE mutation: response to immunosuppressive therapy. J Clin Endocrinol Metab 1999; 84: 844-52.
17. Pun T, Chandurkar V. Growth hormone deficiency, short stature, and juvenile rheumatoid arthritis in a patient with autoimmune polyglandular syndrome type 1: case report and brief review of the literature. ISRN Endocrinology 2011: 462759.

18. Högenauer C, Meyer RL, Netto GJ, Bell D, Little KH, Ferries L. et al. Malabsorption due to cholecystokinin deficiency in a patient with autoimmune polyglandular syndrome type I. N Engl J Med 2001; 344: 270-4.

19. Scarpa R, Alaggio R, Norberto L, Furmaniak J, Chen S, Smith BR et al.Tryptophan hydroxylase autoantibodies as markers of a distinct autoimmune gastrointestinal component of autoimmune polyendocrine syndrome type 1. J Clin Endocrinol Metab 2013; 98: 704-12.

20. Posovszky C, Lahr G, von Schnurbein J, Buderus S, Findeisen A, Schröder C. et al. Loss of enteroendocrine cells in autoimmunepolyendocrine-candidiasis-ectodermal-dystrophy (APECED) syndrome with gastrointestinal dysfunction. J Clin Endocrinol Metab 2012; 97: E292-300.

21. Padeh S, Theodor R, Jonas A, Passwell JH. Severe malabsorption in autoimmune polyendocrinopathy-candidosis-ectodermal dystrophy syndrome successfully treated with immunosuppression. Arch Dis Child 1997; 76: 532-4.

22. Kluger N, Jokinen M, Krohn K, Rankl A. What is the burden of living with autoimmune polyendocrinopathy candidiasis ectodermal dystrophy (APECED) in 2012? A health-related quality-of-life assessement in Finnish patients. Clin Endocrinol 2013; 79: 134-41.

23. Scott HS, Heino M, Peterson P, Mittaz L, Lalioti MD, Betterle C. et al. Common mutations in autoimmune polyendocrinopathy-candidiasisectodermal dystrophy patients of different origins. Mol Endocrinol 1998; 12: 1112-9.

24. Cihakova D, Trebusak K, Heino M, Fadeyev V, Tiulpakov A, Battelino T. et al. Novel AIRE mutations and P450 cytochrome autoantibodies in Central and Eastern European patients with APECED. Hum Mutat 2001; 18: 225-32.

25. Myhre AG, Halonen M, Eskelin P, Ekwall O, Hedstrand H, Rorsman F. et al. Autoimmune polyendocrine syndrome type 1 (APS I) in Norway. Clin Endocrinol 2001; 54: 211-7.

26. Meloni A, Willcox N, Meager A, Atzeni M, Wolf ASB, Husebye ES. et al. Autoimmune poyglandular syndrome type 1: an extensive longitudinal study in Sardinian patients. J Clin Endocrinol Metab 2012; 97: 1114-24.

27. Wolff AS, Sarkadi AK, Maródi L, Kärner J, Orlova E, Oftedal BE. et al. Anti-cytokine autoantibodies preceding onset of autoimmune polyendocrine syndrome type I features in early childhood. J Clin Immunol 2013; 33: 1341-8. 